\title{
A Sand Budget for Marble Canyon, Arizona-Implications for Long-Term Monitoring of Sand Storage Change
}

ecent U.S. Geological Survey
research is providing important
insights into how best to monitor
changes in the amount of tributary-
derived sand stored on the bed of
the Colorado River and in eddies in
Marble Canyon, Arizona. Before the
construction of Glen Canyon Dam and
other dams upstream, sandbars in
Glen, Marble, and Grand Canyons were
replenished each year by sediment-
rich floods. Sand input into the
Colorado River is crucial to protecting
endangered native fish, animals, and
plants and cultural and recreational
resources along the river in Glen
Canyon National Recreation Area and
Grand Canyon National Park.

There is longstanding interest in the condition and trend of river-related resources in and along the Colorado River in Glen Canyon National Recreation Area and Grand Canyon National Park, Arizona. These resources include endangered native fish, native riparian flora and fauna (plants and animals that live along streams), riverside campsites, and many sites of cultural significance to Native Americans. The physical underpinnings for many of these resources are river-deposited sandbars that occur intermittently along the banks of more than 300 miles of the Colorado River in Glen, Marble, and Grand Canyons.

In the Colorado River, most sandbars form along the shoreline in eddies, which are areas of recirculating, relatively low velocity flow. The sandbars are typically inundated during floods and exposed at times of low stream flow. Before the completion of Glen Canyon Dam in 1963 and the construction of other large dams upstream, sandbars were replenished each year by sediment-rich floods. Sandbars are now smaller because Lake Powell, the nearly 200-mile long reservoir formed by the dam, traps all upstream sediment before it reaches the canyons downstream. The sandbars that remain in Glen, Marble,

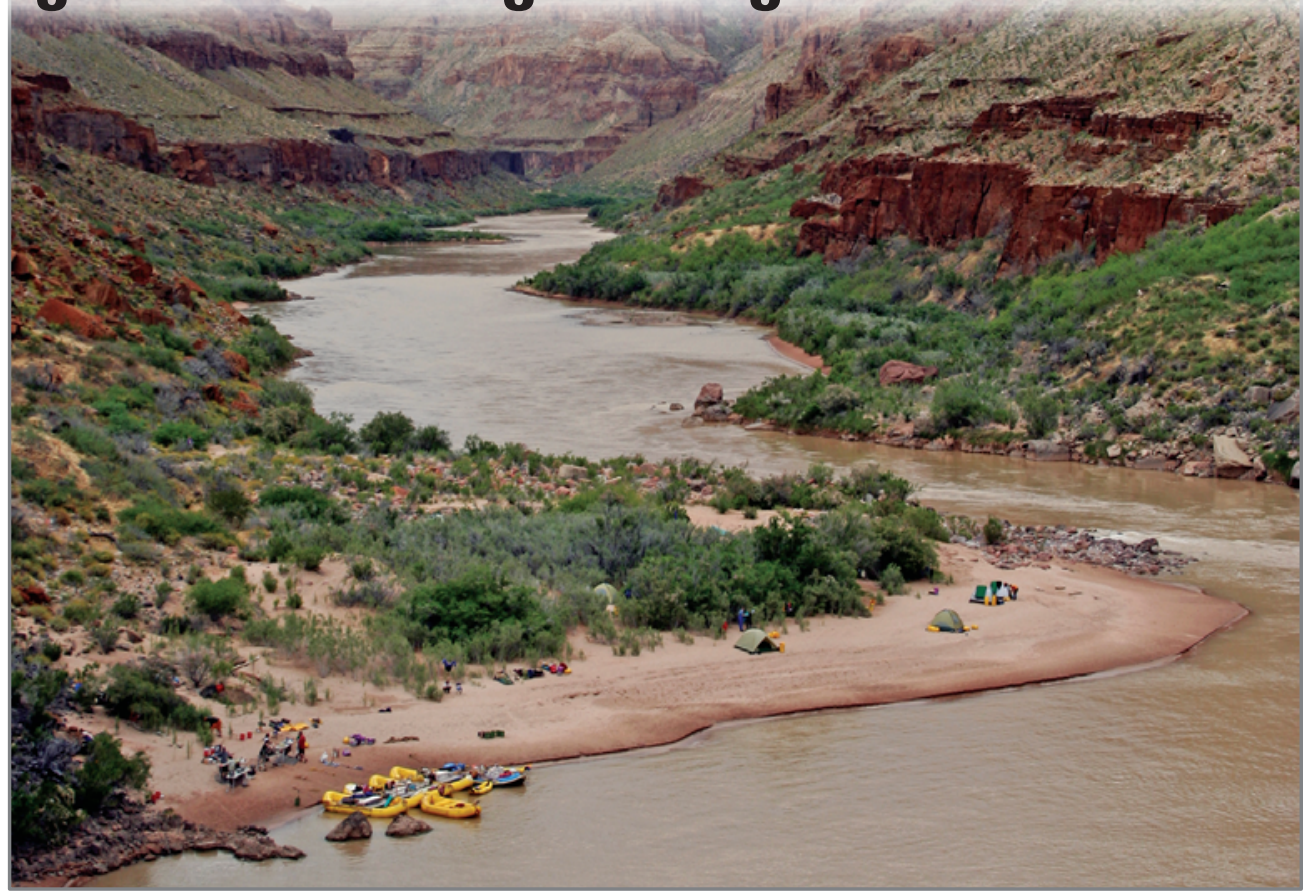

View of the Colorado River in Grand Canyon, Arizona, showing sandbars that form downstream from tributary debris fans, which constrict the flow of the river and cause eddies. The view is looking upstream at a point approximately 217 miles downstream from Glen Canyon Dam. (Photo by Sam Jansen.)

and Grand Canyons are maintained by replenishment of sand that is supplied by tributaries and redistributed by occasional controlled floods released from Lake Powell. The two largest sources of tributary sand are the Paria and Little Colorado Rivers, which enter the Colorado River 17 and 79 miles downstream from the dam, respectively. The sand delivered by these tributaries is temporarily stored on the riverbed until the water released during controlled floods transports it to sandbars along the river's banks.

\section{Sandbars in Grand Canyon- Previous Research}

Decline in the size and abundance of sandbars since the pre-Glen Canyon Dam era has been documented by analysis of old aerial and ground-level photographs and by topographic surveys that began in the mid-1970s. Scientists have estimated that sandbar area in the upstream 100 miles of Glen, Marble, and Grand Canyons was 25 percent less in 2000 than in average pre-dam years (Wright and others, 2005). This decline occurred because releases of water from Lake Powell are virtually free of sediment. The tributaries that enter the Colorado River downstream from the dam supply only a fraction of the pre-dam sand supply (Topping and others, 2000), and the capacity of the post-dam river to transport that sand greatly exceeds this limited supply. Normal dam operations, therefore, tend to erode, rather than build, sandbars.

By experimentation, scientists have learned that controlled floods, if released from the reservoir immediately following large inputs of sand from tributaries, can build sandbars (Schmidt and Grams, 2011). These sandbars are built during controlled floods when sand is carried from the riverbed and temporarily suspended at high concentration in the flow. The suspended sand is transported into eddies where it is then deposited in areas of low stream-flow velocity. Sandbars enlarged by this process provide larger camping beaches for river-rafting trips and create backwater habitats used by native fish. Newly deposited sandbars also provide areas for riparian vegetation 
to grow and are a source of windblown sand. Windblown sand carried upslope from sandbars helps to cover and potentially preserve some of the culturally significant archeological sites in Grand Canyon (Draut and Rubin, 2008).

Scientists have also learned that controlled floods may erode sandbars if the concentration of suspended sand during a controlled flood is too low. The concentration of sand during a flood is directly proportional to the amount of the riverbed covered by sand and the size of that sand. Higher concentrations of suspended sand occur when the sand is relatively fine and large amounts of the riverbed are covered by sand. These findings are incorporated in the current reservoir-release management strategy for Glen Canyon Dam, which involves releasing controlled floodsadministratively referred to as High Flow Experiments (HFEs) — whenever the Paria River has recently delivered large amounts of sand to the Colorado River. The magnitude and duration of the controlled floods is adjusted to transport just the amount of sand that has recently been delivered from the Paria River.

In support of the protocol to implement HFEs, the U.S. Geological Survey's Grand Canyon Monitoring and Research Center (GCMRC) monitors the amount of sand supplied from the Paria River and other tributaries and measures the size and distribution of sand on the riverbed and in eddies. Data on long-term trends in the amount of sand stored on the riverbed and in eddies allows scientists to evaluate whether the cumulative effect of the recently adopted HFE management strategy is causing a net increase or decrease in the size and volume of sand deposits along the Colorado River. A significant and progressive decline in sand storage would indicate that sandbars created during controlled floods are short-lived and that the total volume of sandbars is declining. Such a long-term decline in sand storage would likely result in declining future effectiveness of HFEs in maintaining desired sandbar size.

\section{Recent Findings-How Much Sand is in the River?}

Although sandbars that are exposed above the water surface are the resources of management interest, the visible part of a sandbar represents only 10 to 20 percent of the total sandbar. Like icebergs, a small exposed sandbar is merely the highest part of a much larger sandbar, most of which is submerged. Thus, tracking trends in sand storage requires tracking both the exposed and submerged parts of sandbars, as well as the total amount of sand stored elsewhere on the riverbed. Monitoring the submerged parts of sandbars in the Colorado River has required the development of specialized methods.

Two complementary methods are used to monitor changes in sand deposits for long segments of the Colorado River. The flux-based method for measuring changes in sand deposits is based on measurements of total sand transport, referred to as "flux," past measurement stations spaced 30 to 60 miles apart. The difference in flux between stations represents the amount of sand that has been deposited in or eroded from the intervening river segment. Because stations operate continuously, this method provides a continuous record of changes in storage between the measurement stations. These continuous measurements can be compared to dam releases during the same time period to better understand how dam operations affect sandbar resources. Disadvantages of this method are that uncertainty grows in proportion to the length of the monitoring period and that it does not provide information about how much each individual sand deposit changed within each long river segment. The alternative method to measure change in sand deposits

Before the construction of Glen Canyon Dam and other dams upstream, sandbars in Glen, Marble, and Grand Canyons, Arizona, were replenished each year by sediment-rich floods. To provide information crucial to managing these sandbars, U.S. Geological Survey scientists are monitoring changes in sandbars and the amount of sediment supplied to the river in Marble Canyon. This map shows the locations of the five short (less than 3 mile) monitoring reaches used to measure topographic changes in sandbars and the locations of stream-flow and sediment-transport measurement stations. The brown-shaded area is within Grand Canyon National Park. Glen Canyon extends from Glen Canyon Dam to Lees Ferry; upper Marble Canyon extends from Lees Ferry to river mile (RM) 30; lower Marble Canyon extends from RM 30 to RM 61; and Grand Canyon begins at RM 61 . is based on repeat measurements of the underwater topography of the sand deposits using an instrument called a multibeam echosounder. This topographic method, for which uncertainty does not increase for longer monitoring periods, provides a relatively precise portrayal of the locations and amounts of changes in sand deposits. Repeat topographic measurements are, however, difficult to implement over long river segments and are made infrequently.

Flux-based measurements are ideally suited to monitoring short-term changes in sand storage, which are essential for making decisions about dam operations. Topographic measurements, on the other hand, are more appropriate for monitoring long-term trends in the deposits, which are needed to evaluate the cumulative effect of management actions over several years. Grams and others (2013) integrated these two measurement methods for the 61-mile length of Marble Canyon. Because mapping channel topography is time consuming and costly, five short (less than 3 mile) reaches were selected for monitoring as a practical alternative to mapping the entire 61-mile segment. For such an approach to be successful, topographic changes in the monitoring reaches must be representative of changes throughout the study area. Thus, the primary purpose of the study was to compare the two measurement methods and thereby determine if this sampling strategy could be $112^{\circ} \mathrm{W}$

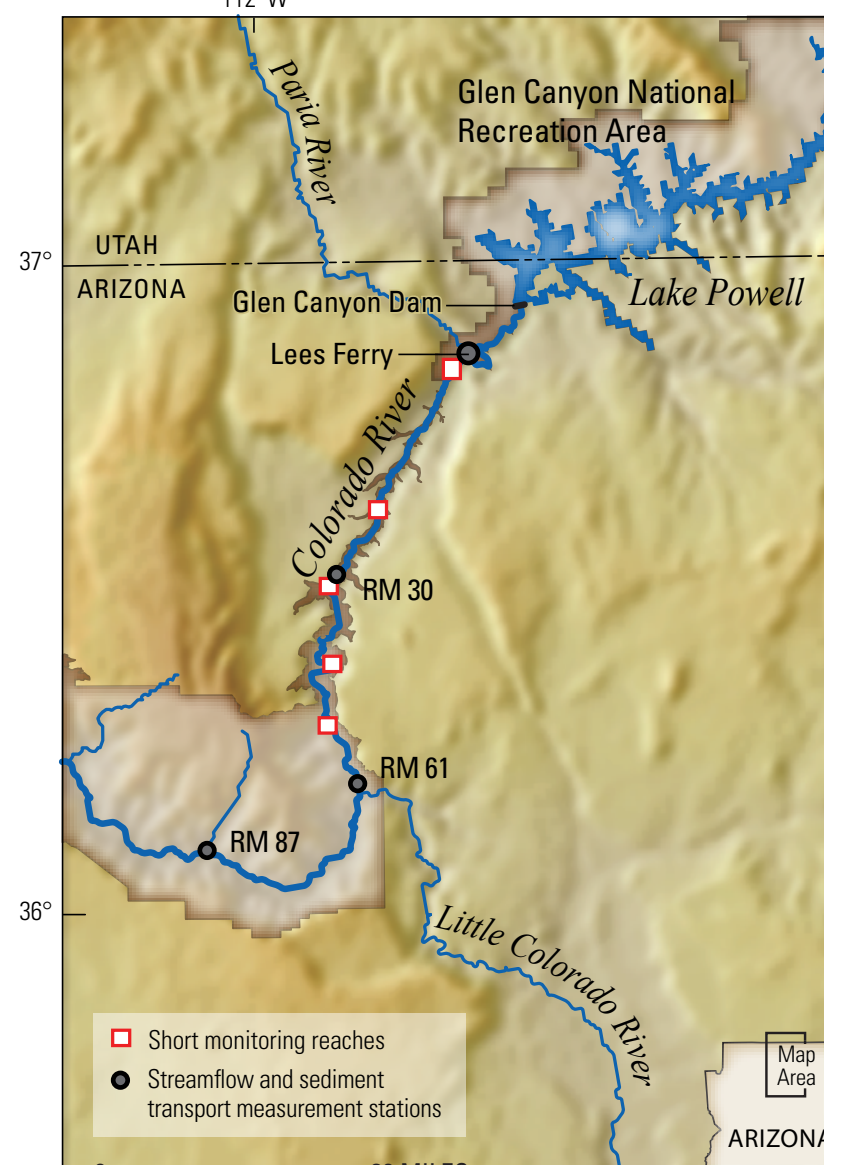



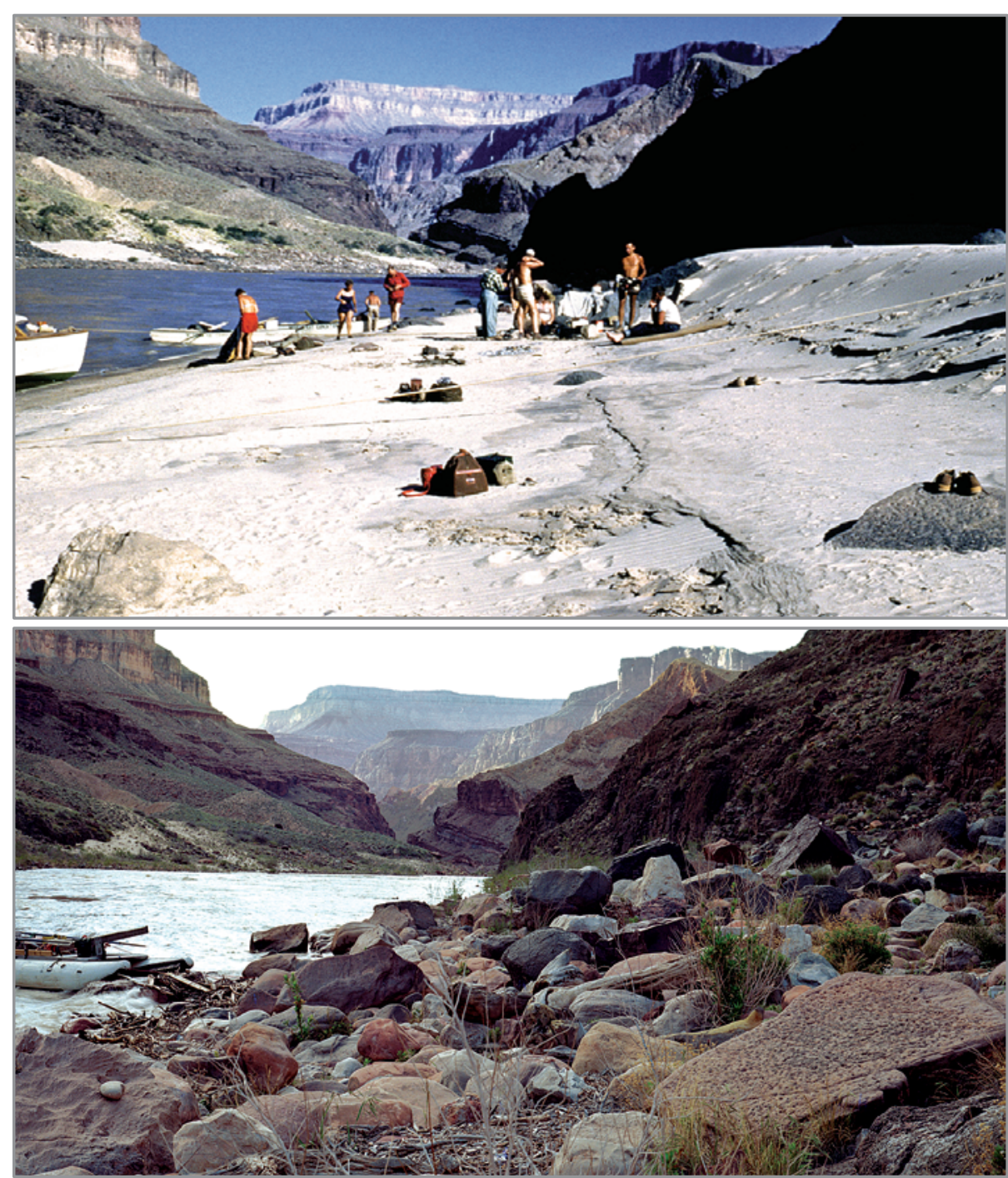

Glen Canyon Dam was completed in 1963, affecting stream flow and sand movement in the Colorado River below the dam. These photographs show the river in Grand Canyon, 150 miles downstream from the dam. The top image taken in 1952 shows a large sandbar; in the bottom image taken in 2003 little sand remains. View is downstream from the right (north) bank of the river. (Photos courtesy of Kent Frost, top, and Steve Tharnstrom, bottom; from Webb and others, 2002.)

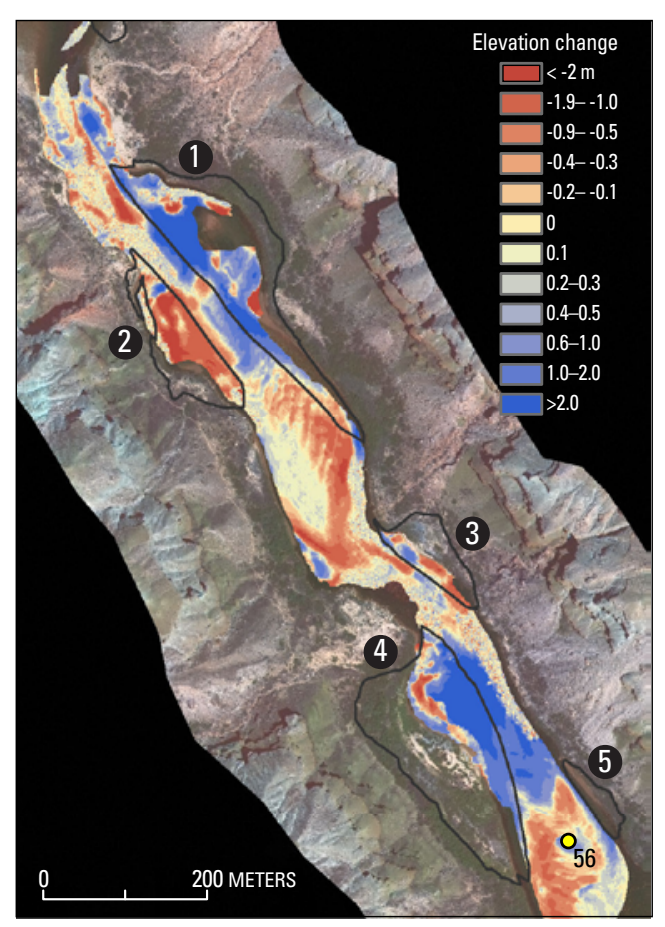

This aerial image with superimposed map shows areas of erosion (red) and deposition (blue) between December 2004 and May 2009 for a segment of the short monitoring reach near river mile 56 in Marble Canyon (see map). A multibeam echosounder was used to measure the changes in the underwater topography of sediment deposits. The numbered gray outlines show individual eddies, where changes in sediment storage are entirely sand. Of the three largest eddies in this short river segment, one (2) is almost entirely dominated by erosion and two ( 1 and 4 ) are dominated by deposition. The Colorado River channel outside of the eddies includes areas of deposition and erosion. (Changes in elevation shown in meters $(\mathrm{m}) ; 1 \mathrm{~m}=\sim 3.28$ feet. $<$, less than; >, greater than.) used to reliably track long-term trends in sand storage.

Each of the short topographic monitoring reaches was mapped at least four different times between 2002 and 2009. Comparison of the maps for different times allowed determination of the amount and spatial pattern of changes in riverbed and eddy sand deposits. These results were compared with sediment-flux measurements spanning the same time periods.

The repeated mapping of riverbed topography demonstrates that very large changes in individual sand deposits can occur in the Colorado River in Marble Canyon. Adjacent sand deposits often change in different ways — one deposit may erode greatly, but another nearby deposit may grow significantly. For example, between December 2004 and May 2009, some parts of the river channel near river mile 56 eroded, whereas other areas accumulated sand. Grams and others (2013) also found that local changes in the topography of sand deposits are very large when compared to the changes in storage calculated from flux-based measurements. The amount of sand that is either deposited or eroded from just a few hundred yards of river channel can equal the total change in sand storage for an entire 30-mile river segment.

Thus, changes in sand storage that are measured over long segments of the river channel by the flux-based measurement program are not the result of uniform changes evenly distributed throughout the channel. Instead, changes in sand storage that are measured over long segments result from the sum of topographic changes in (1) small areas where there has been large erosion and (2) other areas where there has been large deposition. This finding highlights the difficulty in identifying short "representative" topographic monitoring reaches for extending results to longer river segments. Changes measured at a few locations in a few short reaches are unlikely to be representative of the average topographic response over a long segment of the Colorado River.

\section{The "Sand Budget"}

Tracking sand storage in Grand Canyon is like managing a budget or a bank account. "Deposits to the account" occur when sand is supplied by tributaries, but these "deposits" are typically only made to the riverbed. Sand transported further downstream towards Lake Mead reservoir (along the ArizonaNevada border) by normal dam operations and controlled floods are withdrawals from the account. Sandbars built during controlled floods may be viewed as "transfers" from the "riverbed account" to the "eddy sandbar account." Thus, it is essential that river managers are provided information about the amount of sand in the total bank account, the amount of sand in the eddy sandbar 


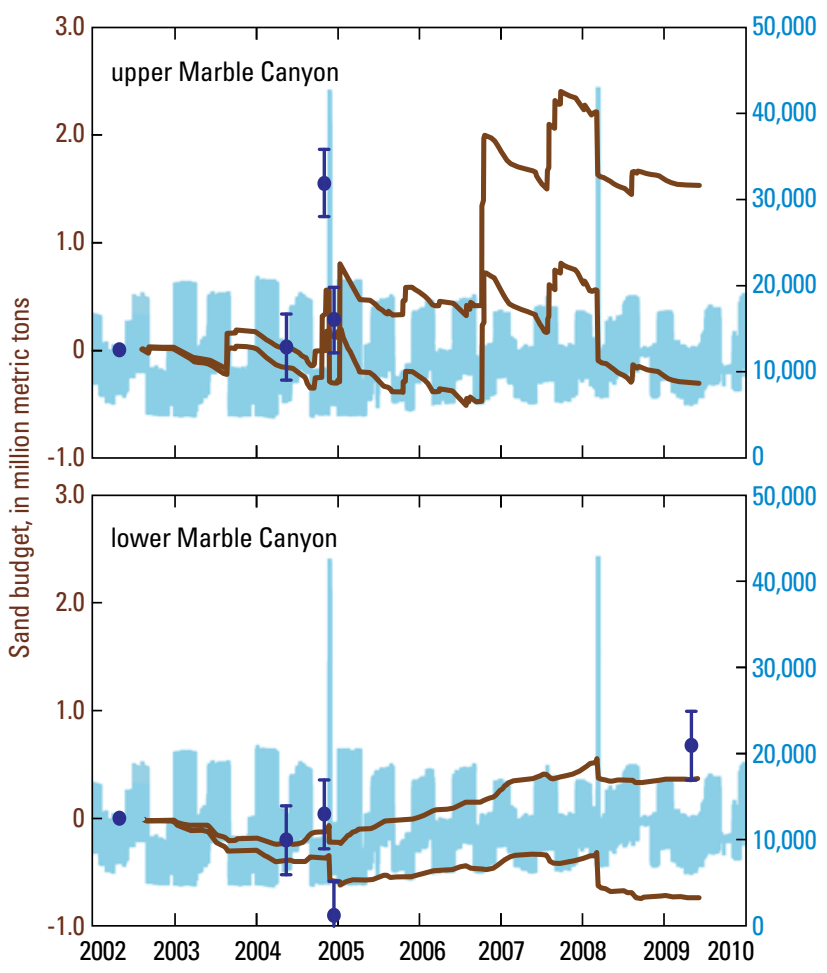

$50,000 \quad$ These graphs show the "sand budget" (sand available to build sandbars) for upper and lower Marble Canyon, as well as Colorado River water discharged from Glen Canyon Dam, during 2002-2009. The solid brown lines show the sand budget based on sediment flux recorded at measurement stations (see map). The upper solid line is the upper limit of the uncertainty range, and the lower line is the lower limit of the uncertainty range. The blue dots with "error bars" show the sand budget based on repeat measurements of the topography of sand deposits. The error bars show the estimated measurement error. These estimates have additional uncertainty (not shown) associated with the extrapolation from short monitoring reaches (see map) to the 30 -mile river segments between measurement stations. The thick blue lines are discharge measured at Lees Ferry. (1 metric ton $=\sim 1.10$ U.S. short ton.)

account, and the amount of sand that has been withdrawn from the account and transported to Lake Mead.

Repeat topographic mapping of the riverbed shows where large deposits and withdrawals of sand from the account typically occur. Grams and others (2013) showed that the sand is stored in hundreds of separate accounts, some larger than others, distributed throughout the river channel. Understanding this sand budget - where the sand-storage locations are, the size of these accounts, and how much these accounts change - is essential to improving predictions about how dam operations will affect sand storage and, ultimately, sandbars.

The sand budget also showed that between 2002 and 2009 there were periods of depletion of sand from storage and periods of accumulation of sand in storage. Sand storage always declined between tributary sediment input events, whereas tributary sand inputs in 2006, 2007, and 2008 were large and resulted in progressive sand accumulation. Although much of this sand was transported downstream in the March 2008 controlled flood (that is, a "withdrawal" from the account), some of this sand was transferred to newly enlarged eddy sandbars or remained on the riverbed.

\section{Management Implications}

Because the absolute quantity of sand available to build sandbars along the Colorado River cannot be reliably measured, the only option is to measure trends in sand storagethat is, changes in the size of eddy sandbars and changes in the amount of sand on the riverbed. Initial results from efforts to monitor these long-term trends in storage indicate that storage in Marble Canyon did not decline between 2002 and 2009. This period was one of average to above average tributary sand inputs and average to below average dam release volumes. Grams and others (2013) conducted their study during a period that was favorable to sand accumulation. Periods when dam release volumes are greater and tributary sediment inputs are less frequent will likely result in less sand accumulation. Grams and others (2013) showed that measurements of channel change made in short reaches can be used to track changes in deposits and transfers of sand among the storage locations, but the results cannot be extrapolated to long segments of the river, because the size and distribution of sand storage locations is highly variable.

\section{Next Steps}

On the basis of the above findings, GCMRC scientists and cooperators now measure topographic changes over long segments of the Colorado River channel. Instead of monitoring short reaches, which are unlikely to be representative of the entire system, scientists now map a much larger proportion of the sand-storage locations in long river segments. This monitoring strategy will provide a detailed accounting of the changes in sand deposits for entire 30-mile monitoring segments. Scientists will learn much more about the size, distribution, and behavior of those sand-storage locations that are of significant management interest, hopefully enabling development of a more cost-effective and spatially representative sandbar monitoring program.

\section{References Cited}

Draut, A.E., and Rubin, D.M., 2008, The role of eolian sediment in the preservation of archeologic sites along the Colorado River corridor in Grand Canyon National Park, U.S. Geological Survey Professional Paper 1756, 71 p., available at http://pubs.usgs.gov/pp/1756/.

Grams, P.E., Topping, D.J., Schmidt, J.C., Hazel, J.E., and Kaplinski, M., 2013, Linking morphodynamic response with sediment mass balance on the Colorado River in Marble Canyon-Issues of scale, geomorphic setting, and sampling design: Journal of Geophysical Research, v. 118, no. 2, p. 361-381, doi: 10.1002/jgrf.20050, accessed July 29, 2013, at http://onlinelibrary.wiley.com/doi/10.1002/ jgrf.20050/abstract.

Schmidt, J.C., and Grams, P.E., 2011, The high flows - Physical science results, in Melis, T.S., ed., Effects of three high-flow experiments on the Colorado River ecosystem downstream from Glen Canyon Dam, Arizona: U.S. Geological Survey Circular 1366, p. 53-91, available at http://pubs.usgs.gov/circ/1366/.

Topping, D.J., Rubin, D.M., and Vierra, L.E., 2000, Colorado River sediment transport - 1 ; natural sediment supply limitation and the influence of Glen Canyon Dam: Water Resources Research, v. 36, no. 2, p. 515-542, doi: 10.1029/1999WR900285, accessed July 29, 2013, http://onlinelibrary.wiley.com/ doi/10.1029/1999WR900285/abstract.

Webb, R.H., Melis, T.S., and Valdez, R.A., 2002, Observations of environmental change in Grand Canyon: U.S. Geological Survey WaterResources Investigations Report 02-4080, 33 p., available at http://pubs.usgs.gov/wri/wri024080/.

Wright, S.A., Melis, T.S., Topping, D.J., and Rubin, D.M., 2005, Influence of Glen Canyon Dam operations on downstream sand resources of the Colorado River in Grand Canyon, in Gloss, S.P., Lovich, J.E., and Melis, T.S., eds., The state of the Colorado River ecosystem in Grand Canyon: U.S. Geological Survey Circular 1282, p. 17-31, available at http://pubs.usgs.gov/ circ/1282/.

\section{Paul E. Grams}

Edited by James W. Hendley II Graphics and layout by Jeanne S. DiLeo

For more information contact:

$$
\text { U.S. Geological Survey }
$$

Southwest Biological Science Center Grand Canyon Monitoring and Research Center 2255 N. Gemini Drive Flagstaff, AZ 86001

(928) 556-7094

http://www.gcmrc.gov/

This fact sheet and any updates to it are available online at http://pubs.usgs.gov/fs/2013/3074/ 